\title{
ANTECEDENTS OF ONLINE OJEK CUSTOMER LOYALTY (CASE STUDY OF STUDENT CUSTOMERS GO-JEK MEDAN)
}

\author{
Imelda Sitinjak \\ Faculty of Economics, HKBP Nommensen University \\ imelda.sitinjak@UHN.ac.id \\ Martin Luter Purba \\ Faculty of Economics, University of HKBP Nommensen \\ martin_purba88@yahoo.com
}

\begin{abstract}
This research is conducted to determine the level of customer loyalty influenced by the antecedents of customer satisfaction, the reasonableness of the price and quality of service, either directly or through customer satisfaction Go-Ride students in Medan. The unit of analysis of this study was individuals, namely female students from universities in Medan who had used Go-Ride. The method of determining the sample used purposive sampling method. Of the 298 data collected, 290 data were used as research samples and processed using the Lisrel 8.72 program. This research tests the quality of services with service quality indicators ofa mass transport from the European Committee for Standardization which has never been used for motorcycle taxis. This study found that there is direct effect of antecedents of customer loyalty such as customer satisfaction and fairness of significant prices on Go-Ride student loyalty in Medan, while service quality has a significant indirect effect on Go-Ride student loyalty in Medan. This research has implications for a business start-up that must pay attention to the antecedents of loyalty, including customer satisfaction, fairness of price, and quality of service, and competitiveness will determine the sustainability of a start-up business because customers with businesses and businesses with businesses have mutually related relationships influence.
\end{abstract}

Keywords: loyalties, antecedents, Go-Ride, Medan

\begin{abstract}
Penelitian ini bertujuan untuk mengetahui tingkat loyalitas pelanggan yang dipengaruhi oleh anteseden-anteseden kepuasan pelanggan, kewajaran harga dan kualitas pelayanan baik langsung atau melalui kepuasan pelangganmahasiswa Go-Ride di Medan.Unit analisis penelitian ini adalah individu yaitu mahasiswi dari universitas-universitas yang ada di Medan yang pernah menggunakan Go-Ride. Metode penentuan sampel digunakan metode purposive sampling. Dari 298 data yang terkumpul, 290 data yang dijadikan sampel penelitian dan diolah menggunakan program Lisrel 8.72. Studi ini menguji kualitas pelayanan dengan indikator kualitas pelayanan sebuah transportasi massadari European Committee for Standarization yang belum pernah digunakan untuk ojek. Studi ini menemukan bahwa pengaruh langsung anteseden-anteseden loyalitas pelanggan seperti kepuasan pelanggan dan kewajaran harga signifikan terhadap loyalitas mahasiswi Go-Ride di Medan, sementara kualitas pelayanan memiliki pengaruh tidak langsung yang signifikan terhadap loyalitas mahasiswi Go-Ride di Medan.Penelitian ini berimplikasi bagi sebuah bisnis start-up yang harus memperhatikan faktor anteseden-anteseden loyalitas antara lain kepuasan pelanggan, kewajaran harga, dan kualitas pelayanan, serta kemampuan bersaing akan menentukan keberlanjutan sebuah bisnis start-up karena pelanggan dengan bisnis dan bisnis dengan bisnis memiliki hubungan yang saling mempengaruhi..
\end{abstract}


Kata Kunci: loyalitas, antesenden-antesenden, Go-Ride, Medan

JEL: M31

\section{Research Background}

Today's business competition cannot be predicted anymore. Large companies that have not been deterred because they have strong resources and control most of the market share in their respective industries, are already worried about the business phenomena that occur. The phenomenon of the development of the concept of economic sharing (Ekonomi Berbagi- EB) along with the development of technology has succeeded in shifting the habits of people who originally wanted to have some resources to just want to rent or borrow (rent or borrow rather than buy). Most EB companies have succeeded even the companies are still classified as start-up such as Uber, Alibaba, Amazon, GO-JEK, Grab, Traveloka, and others.

Indonesia has four start - up labelled as unicorn. Unicorn is a nickname for a start-up that has a valuation of more than US \$ 1 billion (USD - 15, 2 trillion). The four start-ups are Go-Jek, Tokopedia, Traveloka, and BukaLapak (Ananta, 2018). During 2018, GO-JEK as one of the nation's EB in Indonesia, successfully reached approximately transactions 177, 5trillion rupiahs (Sinintya, 2019). This will continue to invite investors such as Alphabet, parent of Google, Temasek from Singapore, Chinese online platform Meituan-Dianping, global private equity firm KKR \& Co LP and Warburg Pincus LLC (Ananta, 2018).

Key success factors of EB companies are speed and acceleration of having new intangible resources such as applications (online platforms), application users (traffic), database, and reputation (Turino 2016).GO-JEK, as one of the EB companies of Indonesian, has a GO-JEK application on the Play Store (2018) which has been downloaded by more than 50 million users, has partnered with more than 1 million drivers, 125 thousand culinary traders, and 30 thousand other service providers, all of which are spread in 50 cities in Indonesia. For sustainability business, GO-JEK must maintain intangible assets by securing user loyalty applications and services GO-JEK.

Based on the Sitinjak study (2018), information was obtained that $66 \%$ of $100 \mathrm{GO}$ JEK student customers at HKBP Nommensen University in Medan who used Go-Ride were less than 10 times, even though more than 30\% had used it since the 2015/2016 Odd Semester (for less more than 4 semesters). Likewise, the pre-survey results of the study found that no single person se aggressively recommend or defend GO-JEK maximum. Thus, it can be concluded that the loyalty's intensity and longevity (Quach et al., 2018) of Go-Ride student customers in Medan UHN is still relatively low.

The low level of GO-JEK customer loyalty is influenced by the feeling of no satisfaction with the security of application user data, as stated by the technology observer and Executive Director of the if ICT Watch, Donny Budi Utoyo in Nistanto 2016. In addition, presurvey studies Sitinjak (2018) obtained the complaints of customers GO-JEK among other drivers do not use these attributes is complete, the driver cancel orders, difficult to get a driver if the destination is too far away, the prices vary according to hours, and so on. These complaints show lack of satisfaction with the quality of service and the reasonableness of the price for Go-Jek customers. A number of studies on GO-JEK found factors that influence customer loyalty including satisfaction, marketing mix, and trust such as studies in Surabaya (Mar'ati and Sudarwanto 2016), in Semarang ( Setyaji and Ngatno 2016), in Jakarta (Rizan et al. 2015), and Tangerang (Berlianto 2017), in Purba Medan (2017) and Sitinjak (2018) .

This study was also preceded by Sitinjak's study (2018) which examined the effect of fairness of prices and service quality on loyalty mediated satisfaction with HKBP Nommensen 
University students. The results show that the fairness of prices has a significant and positive effect on loyalty both directly and through satisfaction mediation, while service quality has no significant effect on loyalty either directly or indirectly. For the progress of the study, this study updated service quality indicators with service quality standards for mass transportation (European Committee for Standardization 2002) which were also used by previous studies Silalahi (2017), and Santoso and Nelloh (2017). In addition, the respondents used were also expanded to female university students in Medan. This study found a gap that is combining antecedents of customer loyalty, among others, customer satisfaction, service quality, and fairness of prices. Thus, this study aims to determine the significance of the effect of the antecedents on the loyalty of GO-JEK student customers in the city of Medan.

\subsection{Theoretical Framework and Hypotheses}

Customer loyalty is a situation where there is a strong commitment in repurchasing and reusing company goods or services (Kotler and Keller 2009). In Kotler and Keller (2009), Oliver defines loyalty as a deeply held commitment to buy or support a product or service that is favoured in the future even though the influence of the situation and marketing efforts have the potential to cause customers to switch.

Table 1. Loyalty Transformations

\begin{tabular}{|c|c|c|c|c|}
\hline \multicolumn{3}{|c|}{ Evolutionary patterns of loyalty } & \multirow{2}{*}{$\begin{array}{l}\text { Intensity } \\
\text { High }\end{array}$} & \multirow{2}{*}{$\begin{array}{l}\text { Longevity } \\
\text { High }\end{array}$} \\
\hline $\begin{array}{l}\text { The rise of The Empire } \\
\text { State of Loyalty }\end{array}$ & & Fanaticism & & \\
\hline \multirow[t]{4}{*}{ The fall } & The transition & Habitual loyalty & Low & High \\
\hline & & $\begin{array}{l}\text { Indifference (Multi-loyalty } \\
\text { (splitter) }\end{array}$ & Low & Low \\
\hline & $\begin{array}{l}\text { The point of } \\
\text { disinterest }\end{array}$ & Strangers & None & None \\
\hline & $\begin{array}{l}\text { Loyalty } \\
\text { backfires }\end{array}$ & $\begin{array}{l}\text { Customer betrayal } \\
\text { retaliation (enemies) }\end{array}$ & $\begin{array}{l}\text { Highly } \\
\text { negative }\end{array}$ & $\begin{array}{l}\text { Highly } \\
\text { negative }\end{array}$ \\
\hline
\end{tabular}

Source: Quach, et al. (2018)

To determine the level of customer loyalty, Quach et al. (2018) make two fundamental criteria, namely intensity and longevity. Intensity refers to the depth of customer feelings towards a company or product. High customer intensity shows the tendency of customers to express their loyalty aggressively in many ways. While longevity refers to how long customer relationships are established with the company. Longevity of high customer showed customer relationships with enterprise customers belongs to a lifetime.

Researchers at Sitinjak (2018), Setyaji and Ngatno (2016) and Berlianto (2017) found that there was a significant effect of customer satisfaction on GO-JEK customer loyalty. According to Kotler and Keller (2009) satisfaction is the level of one's feelings after comparing the performance (or results) that he feels compared to his expectations. By that, the level of satisfaction is a function of the difference between perceived performance and expectations. Customers can experience one of three general levels of satisfaction. If the performance is below expectations, the customer will be disappointed. If the performance is as expected, the customer will feel satisfied. If performance exceeds expectations, customers will be very satisfied, happy or happy. Based on the description above, it is hypothesized that: H1: There is a significant antecedent effect of Customer Satisfaction (ServQual) on GO-JEK Student Loyalty in Medan. 
In service industry, research by Mar'ati and Sudarwanto (2015) shows the dominant effect of prices on GO-JEK customer satisfaction in Surabaya. Sitinjak (2018), Rizan et al. (2015), as well as Bei and Chiao (2001) found that perceptions of reasonable prices significantly influence customer loyalty directly. Kotler and Keller (2009) state that prices are the amount of money charged on a product or service or the amount of value that consumers exchange for benefits because they own or use the product or service. Price is an effort to determine the selling price of a product in order to compete with other products of the same type or with the same quality. Prices must be set competitively by considering various factors, including cost factors (internal company) and market environment factors. Based on the description above, it is hypothesized that:

$\mathrm{H} 2 \mathrm{a}$ : There is a (direct) effect of antecedents of Fairness Price ( PriFair ) which is significant to Customer Loyalty (Loyalty)

H2b: There is a significant (indirect) effect of the Fairness of Price (PriFair) on Customer Loyalty through Customer Satisfaction ( ServQual)

Setyaji and Ngatno (2016), Purba (2017), and Mar'ati and Sudarwanto (2016) examined that service quality significantly influences directly or through customer satisfaction with GO-JEK customer loyalty .According to Polyorat and Sophonsiri (2010: 67) it has identified service quality as a determinant of customer loyalty, while Cristobal et al (2007) suggested that service quality first affects customer satisfaction which then affects loyalty. Quality provides an incentive for customers to establish strong ties or relationships with the company. Tjiptono (2008) explains that service quality focuses on efforts to meet customer needs and the accuracy of delivery to keep up with customer expectations. Experience served well can be experiences that are not offered by competitors, or actually not thought or expected by customers. Achieving customer expectations is successful if customers feel a new experience that is more comfortable and more satisfying than previous experience. Service quality can be evaluated by comparing the quality experienced or received by the company's customers with the expected service. Based on the description above, it is hypothesized that:

H3 A: There is the influence (direct)antecedents Quality of Service (Satisfy)significantly to Customer Loyalty (Loyalty)

H3b: influences of (indirect) antecedents Quality of Service (Satisfy) significantly to Customer Loyalty (Loyalty) through the Customer Satisfaction (ServQual)

\section{Research Method}

In this study, quantitative methods were used with individual analysis units, namely female students GO-JEK (Go-Ride) in Medan. The method of determining the sample in this study used a non-probability sampling and purposive sampling with criteria of university students in Medan, women, and had been using the Go-Ride. Female customers were chosen because the number of female customers was $92 \%$ of respondents in the Sitinjak study (2018). Primary data was obtained through a questionnaire. This research questionnaire used ordinal scale 1-6 with sequential information from 1-6, among others, Strongly Disagree, Disagree, Tends to Disagree, Tends to Agree, Agree, Strongly Agree. Scale was used to avoid the tendency of respondents to answer doubt or neutral (middle value). The main method of collecting primary data in this study is through a questionnaire with the combined Snowball technique. Questionnaires were given to students who were known to meet the sample criteria, then they were asked to distribute questionnaires to be filled out by people they knew also met the sample criteria. In addition, the researcher also assigned several students to go to campuses in Medan and gave questionnaires to students using GO-JEK and then asked them to give their friends who met the sample criteria.

The pre-test sample of this study was GO-JEK (Go-Ride) female students at the HKBP Nommensen University Faculty of Economics, Medan. Data collection from this pretest sample is distributed through online surveys ( http://bit.ly/2MadF4Z) for about 1 
month. After the pre-test sample questionnaire was collected as many as 30 respondents, validity and reliability were tested and then 'wording' was carried out on invalid questionnaires to be used in the study sample. The research sample was also disseminated through online surveys (http://bit.ly/2LCIQ7U ) and the process of collecting research data is approximately 3 months (June-August) .

The Fairness Variable Price is operationalized as the level of expense or price perceived by GO-JEK (Go-Ride) service users based on 1) affordability of prices seen from consumer purchasing power, 2) conformity of prices of products or services with benefits, and 3) price competitiveness with similar products (competitors). Variables of Customer Satisfaction are operationalized as feelings of pleasure or disappointment felt by post-customers using GO-JEK (Go-Ride ) online motorcycle taxi services regarding 1) feelings of pleasure or disappointment that customers feel for the suitability of the overall service (benefits) based on service providers' promise with reality received or experienced. 2) the feeling of pleasure or disappointment felt by the customer for the suitability of the overall cost (sacrifice) that is estimated based on the provisions of the service provider with the reality received or experienced. 3) the feeling of pleasure or disappointment felt by the customer after comparing his experience using the services of the company with his experience using the services of other companies (competitors). Therefore, this study emphasizes the operationalization of GO-JEK customer satisfaction based on these three things. Service Quality Variables are operationalized as perceptions of service users on the totality of GO-JEK (Go-Ride) features and characteristics of services expressed or implied based on standard transportation quality indicators by The European Committee for Standardization (2002) (Ngoc et al, 2017)and according to the conditions of e-service quality, include 1) availability, 2) accessibility, 3) information, 4) time, 5) customer service, 6) comfort, 7) safety. Customer Loyalty variables are operationalized as determining the choice of post-respondent attitudes using GO-JEK (Go-Ride) regarding 1) repurchase, 2) habit of consuming brands, 3) right likes of brands, 4) determination of brands, 5) belief that certain brands of the best brands, 6) brand recommendations to others.

\section{Result and Discussion}

From a total of 298 questionnaires collected both through online surveys and hard copy, obtained 290 complete data to be used as research data. The descriptive analysis in this study uses cross tabulation (cross tabulation) SPSS version 20 to determine the relationship between the profile of the 290 respondents and the average answer of each research variable.

Table 2. Crosstabulation and Chi-Square Tests Average Group Answers for Fairness Variable Prices (PF Average) for Respondent Profile 


\begin{tabular}{|c|c|c|c|c|c|c|c|c|c|}
\hline & & & Avera & $2 \mathrm{FF}$ & & & & & \\
\hline & & & 1 & 2 & 3 & 4 & 5 & 6 & Total \\
\hline Year & 2011 & Count & 0 & 0 & 0 & 0 & 2 & 0 & 2 \\
\hline & & $\begin{array}{l}\% \text { within } \\
\text { Rata2PF }\end{array}$ & $0.0 \%$ & $0.0 \%$ & $0.0 \%$ & $0.0 \%$ & $1.4 \%$ & $0.0 \%$ &, $7 \%$ \\
\hline & 2012 & Count & 0 & 1 & 0 & 0 & 0 & 1 & 2 \\
\hline & & $\begin{array}{l}\% \text { within } \\
\text { Rata2PF }\end{array}$ & $0.0 \%$ & $25.0 \%$ & $0.0 \%$ & $0.0 \%$ & $0.0 \%$ & $3.7 \%$ &, $7 \%$ \\
\hline & 2013 & Count & 0 & 1 & 2 & 11 & 23 & 4 & 41 \\
\hline & & $\begin{array}{l}\% \text { within } \\
\text { Rata2PF }\end{array}$ & $0.0 \%$ & $25.0 \%$ & $10.0 \%$ & $11.8 \%$ & $16.0 \%$ & $14.8 \%$ & $14.1 \%$ \\
\hline & 2014 & Count & 0 & 0 & 1 & 11 & 17 & 8 & 37 \\
\hline & & $\begin{array}{l}\% \text { within } \\
\text { Rata2PF }\end{array}$ & $0.0 \%$ & $0.0 \%$ & $5.0 \%$ & $11.8 \%$ & $11.8 \%$ & $29.6 \%$ & $12.8 \%$ \\
\hline & 2015 & Count & 0 & 0 & 6 & 22 & 28 & 3 & 59 \\
\hline & & $\begin{array}{l}\% \text { within } \\
\text { Rata2PF }\end{array}$ & $0.0 \%$ & $0.0 \%$ & $30.0 \%$ & $23.7 \%$ & $19.4 \%$ & $11.1 \%$ & $20.3 \%$ \\
\hline & 2016 & Count & 1 & 1 & 5 & 14 & 25 & 3 & 49 \\
\hline & & $\begin{array}{l}\% \text { within } \\
\text { Rata2PF }\end{array}$ & $50.0 \%$ & $25.0 \%$ & $25.0 \%$ & $15.1 \%$ & $17.4 \%$ & $11.1 \%$ & $16.9 \%$ \\
\hline & 2017 & Count & 1 & 1 & 6 & 35 & 49 & 8 & 100 \\
\hline & & $\begin{array}{l}\% \text { within } \\
\text { Rata2PF }\end{array}$ & $50.0 \%$ & $25.0 \%$ & $30.0 \%$ & $37.6 \%$ & $34.0 \%$ & $29.6 \%$ & $34.5 \%$ \\
\hline Total & & Count & 2 & 4 & 20 & 93 & 144 & 27 & 290 \\
\hline
\end{tabular}

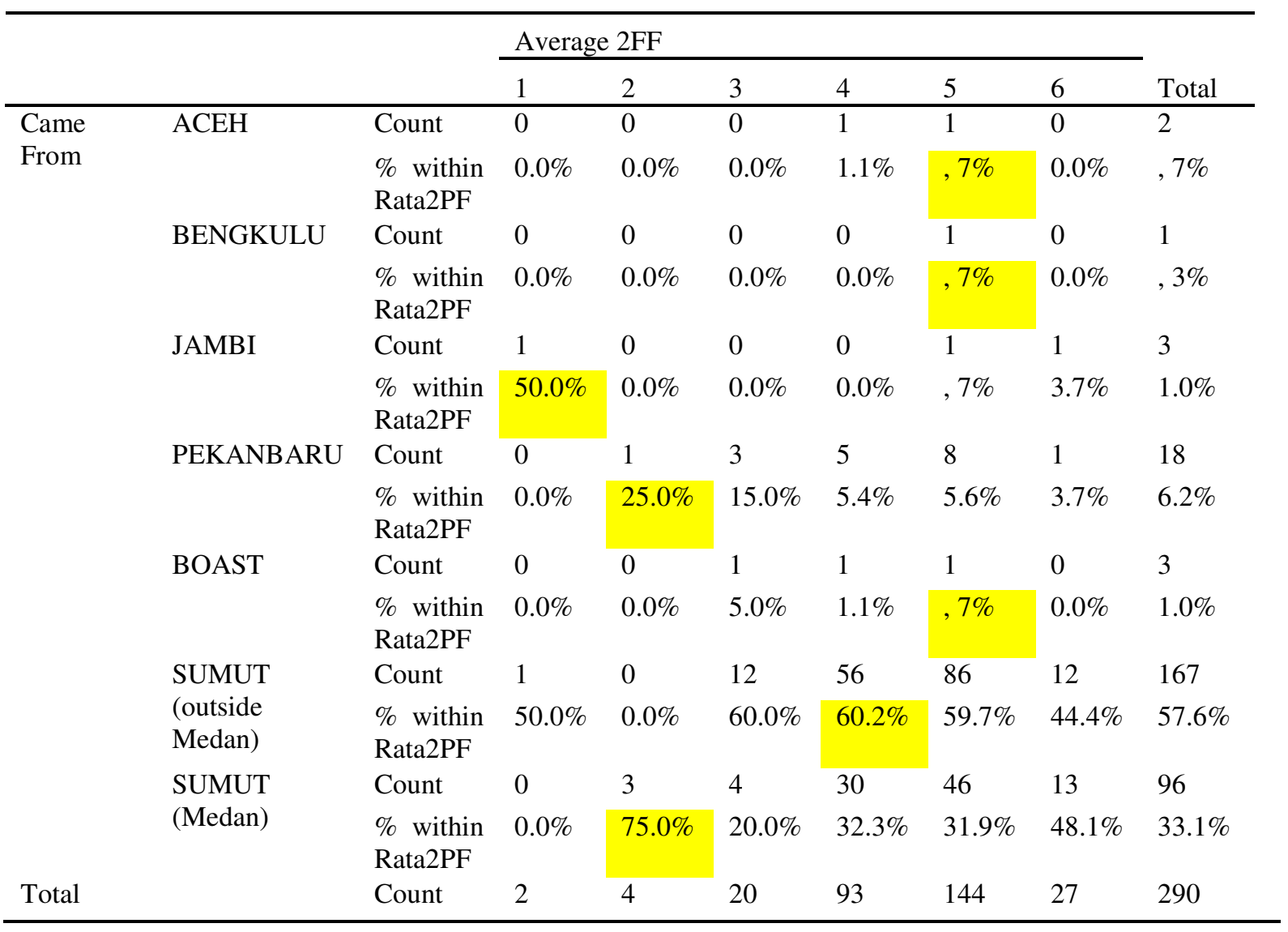


Table 3. Average PF for Year of Entry (Force) Chi-Square Tests

\begin{tabular}{llll} 
& Value & df & Asymp. Sig. (2-sided) \\
\hline Pearson Chi-Square & $58,726^{a}$ & 30 &, 001 \\
Likelihood Ratio & 30,892 & 30 &, 421 \\
Linear-by-Linear Association & 1,941 & 1 &, 164 \\
N of Valid Cases & 290 & & \\
\hline
\end{tabular}

29 cells $(69.0 \%)$ have expected count less than 5 . The minimum expected count is .01 .

Average PF for Regional Origin

Chi-Square Tests

\begin{tabular}{llll} 
& Value & df & Asymp. Sig. (2-sided) \\
\hline Pearson Chi-Square & 69,199 a & 30 & .000 \\
Likelihood Ratio & 29,617 & 30 &, 485 \\
N of Valid Cases & 290 & & \\
\hline
\end{tabular}

a. 32 cells $(76.2 \%)$ have an expected less than 5 . The minimum expected count is .01 .

Based on the chi-square value, it was found that there was a relationship between the average answer of the price fairness variable ( $P F$ average) and the respondent profile (class and regional origin), while the relationships between other variables and other respondents' profiles not significant. For the average fairness of the price (average $P F$ ), the dominant class of 2011 chose to agree, the dominant class of 2012 and 2013 chose to disagree, the dominant class of 2014 voted strongly in favour, the dominant class of 2015 tended to disagree, dominant 2016 and 2017 chose very badly agree. In addition, for the average fairness of the price (average $P F$ ), the dominant origin of Aceh, Bengkulu and West Sumatra regions agreed, from North Sumatra (outside Medan) dominant tended to agree, originating from Pekanbaru and from Medan dominantly disagreeing, as long as the dominant Jambi area strongly disagrees.

Results of confirmatory factor analysis (CFA) stage shows validity indicator because it has Standardized Loading Factor ( SLF) $\geq 0.5$ (Wijanto 2008 ) for each latent variable include Latent PriFair Variables as many as6 indicators from 9 indicators measured, VL (ServQual) as many as 26 indicators from 9 indicators measured, VL (Satisfy) as many as 6 indicators from 7 indicators measured, and VL (Loyalty). ) as many as 6 indicators from 6 indicators measured. While to measure the reliability of valid indicators in SEM can use the composite reliability measure (measure of composite reliability) and variance extracted measure (size of extract variance) with a target $\mathrm{CR} \geq 0.70$, and target $\mathrm{VE} \geq 0.50$. The results showed among others PriFair $(C R=0.81$ and $V E=0.42)$, ServQual $(C R=0.95$ and $V E=$ $0.44)$, Satisfy $(C R=0.88$ and $V E=0.55)$, Loyalty $(C R=0.90$ and $V E=0.60)$. VE value $<0.50$ because of the specified SLF $<0.70$ (Wijanto, 2008). Valid data is measured as a whole (Multiple Factor Measurement Model), with Robust Maximum Likelihood method. Printed output of use values obtained LISREL 8.72 Goodness of Fit Index(GOFI) to model the overall measurement.GOFI, which has a good fit, has represented an absolute match measurement index(RMSEA, ECVI, and GFI), incremental (NNFI, NFI, RFI, IFI, and CFI) and parsimonious (Normed Chi-Square, and AIC), and other GOFI (CN, and p-value). The compatibility of the measurement model in this study is still in accordance with the suggestions of Hair et al. (2006) to report at least one incremental index and one absolute index from GOFI. Therefore, the authors draw the conclusion that the overall measurement model is good. 
The results of the hypothesis test are based on the results of the evaluation of the structural model coefficients by checking the $t$-values of the coefficients or parameters summarized in figure 1.

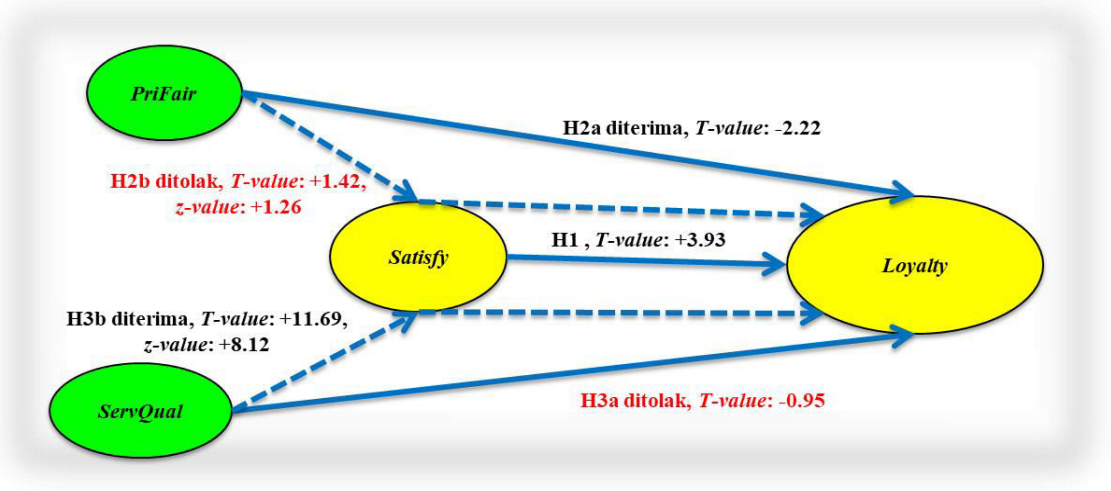

Figure 1. Hypothesis Test Results

Source: adapted from Output Lisrel 8.72

Based on the picture above, Hypothesis testing is done to determine the influence (direct effect) that can be seen from checking the $t$-value of output lisrel 8.72, while for calculating the indirect effect(indirect effect) obtained from the $z$-value calculation of the formula Sobel test with the hypothesis conditions accepted if the value of each \pm 1.96 . The results of the first hypothesis test $(\mathrm{H} 1)$ are accepted because $t$-value is $+3.93 \geq \pm 1.96$. The second hypothesis $(\mathrm{H} 2)$ is accepted with $t$-value $-2.22 \geq \pm$ 1.96. Thethird hypothesis (H2a) d itolak with $z$-value $+1.26<1.96$. $\mathrm{H}$ ipotesis $\quad \mathrm{H} 2 \mathrm{~b}$ rejected with $\mathrm{t}$-value $+1.42< \pm 1.96)$. The fourth hypothesis (H3) is rejected with $t$-value $0.95< \pm 1.96$. The fifth hypothesis $(\mathrm{H} 3 \mathrm{a})$ is accepted since the $t$-value $+8.12 \geq \pm 1.96$. Finally, the hypothesis $\mathrm{H} 3 \mathrm{~b}$ is accepted with $t$-value $+11.69 \geq \pm 1.96$.

While to interpret the coefficient of determination $\left(\mathrm{R}^{2}\right)$ can be taken from the reduced form equation on the printed output of LISREL 8.72. $\mathrm{N}$ value $\mathrm{R}^{2}=0.84$, means that $84 \%$ of the variation in Customer Satisfaction (Satisfy) is explained by variations in Fairness of Price (PriFair) and Service Quality (ServQual). The value of $\mathrm{R}^{2}=0.30$, means that $30 \%$ of the variation on Customer Loyalty (Loyalty) is explained by the variable Customer Satisfaction (Satisfy), Fairness of Price (PriFair) and Service Quality ( ServQual). In general, it can be concluded that as much as $18 \%$ of the variation in Customer Satisfaction, and $70 \%$ of the variation on Customer Loyalty is explained by other variations that have not been found in this study.

This study has proved that hypotheses 1 (H1) received, which means Customer Satisfaction (Satisfy) positive and significant impact on Customer Loyalty (Loyalty) GoRide student in Medan. Positive value means the higher customer satisfaction, the higher the customer loyalty. The customer satisfaction variable which is operationalized as a feeling of pleasure or disappointment felt by post-customers using GO-JEK ( Go-Ride) online motorcycle taxi services is able to encourage Go-Rid efemale customers in Medan to repurchase, have a habit of using Go-Ride, like the right to Go-Ride, determination to Go-Ride, the belief that Go-Ride is the best online motorcycle taxi , and their willingness to recommend Go-Ride to others. Therefore, the results of this study show that in reality the satisfaction of students in Medan in using Go-Ride proven as an antecedent to the formation of Go-Ride customer loyalty in Medan. In other words, to increase customer loyalty, customers must first experience increased satisfaction. The results of this study corroborated by studies of Sitinjak (2018) and Setyaji and Ngatno (2016), which showed a significant effect of customer satisfaction on customer loyalty GO-JEK in Semarang, and Berlianto (2017) that indicates $e$-satisfaction effect on customer loyalty e-Go- JEK in Jakarta. 
The test results on second hypotheses ( $\mathrm{H} 2 \mathrm{a}$ ) is received, which means Fairness Price (PriFair) significant effect on Customer Loyalty (Loyalty) Go-Ride student in Medan. Hypothesis results H2a strengthened with previous studies by Sitinjak (2018), Rizan et al. (2015), and Bei and Chiao (2001) who found that perceptions of reasonable prices significantly influence customer loyalty directly. Based on the Sitinjak study (2018), at that time customers were still trying to move from transportation that was used toGo-Ride so that customers considered the fairness of the price offered by Go-Ride to be loyal. The more reasonable the price offered, the more loyal. This study also proved that the fairness of prices affects the loyalty of female students in Medan. This is due to students' interest $i$ in Medan tend to be sensitive or very concerned about changes in the price of an item or service.

While the results of the $\mathrm{H} 2 \mathrm{~b}$ hypothesis test are rejected which means the fairness of the price (PriFair) does not significantly influence Customer Loyalty when through the satisfaction of Go-Ride students in Medan. The result of hypotheses $\mathrm{H} 2 \mathrm{~b}$ is different from Sitinjak (2018). Likewise, with Mar'ati and Sudarwanto (2016) which actually shows the dominant influence of prices on GO-JEK customer satisfaction in Surabaya. In this study, it was found that the fairness of the price did not significantly affect loyalty when it was preceded by the satisfaction of the Go-Ride student in Medan. Most of the online motorcycle taxi drivers in Medan are still controlled by Go-Ride and Grabbike so customers don't have many choices. In addition, with increasing congestion in the city of Medan, the need for online motorcycle taxis is increasing so that customers do not consider the fairness of prices to get satisfaction in using the Go-Ride in Medan or even repeat the same experience every day.

Negative $t$-value on hypothesis testing $\mathrm{H} 2$ a shows that the more unreasonably priced students feel, the more their loyalty increases. This happens because of competition in determining prices with other online motorcycle taxis. In determining the price or price of online motorcycle taxis, GO-JEK and Grab have different strategies. The Go-Ride price is focused on mileage, which is around Rp.2,500 - Rp.3,000 per kilo meter. Go-Ride relies on GoPay to offer travel discounts of around Rp.1,000 - Rp.2,000 per trip. The Go-Ride pricing strategy has been in effect since its presence in Medan. While Grabbike sets prices that are differentiated based on the high and low demand at certain times. Another strategy, Grabbike offers discounts with different notification codes for each customer. In addition, Grabbike has collaborated with OVO to facilitate non-cash payments and provide discounts for customers using the OVO application. Grabbike categorizes prices with high demand during prime times as before 08 and above 17. At prime time, the price offered tends to be unreasonable (higher than the standard price) according to the customer even though a good discount has been deducted for OVO users or not. Outside of prime time, the Grabbike discount made the price back unreasonable (cheaper than the standard price). Competitor pricing strategies also affect customers in assessing the price of Go-Ride itself. Thus, the price of a motorcycle online unnatural in the sense cheaper than necessary, will increase student customer loyalty in Medan or vice versa.

In this study, it was found that a third hypothesis $(\mathrm{H} 3 \mathrm{a})$ is rejected, which means that the quality of service (ServQual) in significant directly affect customer loyalty (Loyalty) GoRide student in Medan. While service quality (ServQual) significantly influences customer loyalty when preceded by customer satisfaction (hypothesis H3 b is accepted). The customer's consideration for being loyal to Go-Ride does not take into consideration the quality of service directly but customers will experience a satisfying experience in assessing the quality of service of Go-Ride. In other words, customer loyalty is derived from the antecedents of customer satisfaction driven by antecedents of service quality. The results of this study indicate that increasing customer loyalty is influenced by the antecedents of improving service quality through customer satisfaction antecedents. The $\mathrm{H} 3 \mathrm{~b}$ results are reinforced by Setyaji and Ngatno (2016) and Purba (2017) who find that there is a significant effect on service 
quality on customer loyalty through GO-JEK customer satisfaction in Semarang and for Medan Area Medan students. Mar'ati and Sudarwanto (2016) also support that there is a significant influence on the quality of service to GO-JEK customers' satisfaction. This result is in accordance with Cristobal et al (2007) 's suggestion that service quality will affect customer loyalty after first influencing satisfaction.

This result is different from Sitinjak (2018) who found the opposite, namely service quality significantly influences customer loyalty but does not significantly affect loyalty through customer satisfaction at HKBP Nommensen University students in Medan. This is due to the fact that during the study customers were unable to compare the service quality of Go-Ride with others while now it was comparable to the quality of the Grabbike service. The results of the H3a hypothesis test are also different from Setyaji and Ngatno (2016) and Purba (2017) who find that service quality has a significant direct effect on customer loyalty. The results of the H3b hypothesis test are different from Berlianto (2017) who concluded thate-service quality does not affect the e-satisfaction of GOJEK customers in Jakarta.

\section{Conclusion}

The results of this study found that the antecedents of customer satisfaction had a significant effect on the loyalty of Go-Ride female students in Medan. Another finding is that antecedents of fairness of prices have a significant effect on customer loyalty with negative influences. In other words, the more the price is not reasonable, the more customer loyalty increases. Other results indicate that the antecedents of service quality do not have a direct significant effect on loyalty, but have a significant effect when mediated by the satisfaction of Go-Ride female students in Medan. The implication of this study is that the GoRide business unit should use a business strategy cost leadership with a pricing strategy that is right for the people of Medan because the price desired by female students is when the price is getting more unnatural or a lot of big promos and discounts. In addition, management must consistently monitor the quality of driversin providing customer satisfaction. Competitiveness will determine the sustainability of a start-up business because customer relationships with businesses, and businesses and businesses have a mutually influential relationship.

Some limitations of this study are the number of indicators that are too many with consideration to anticipate invalid results, it turns out to influence respondents in filling out the questionnaire. For now, respondents still need encouragement to fill through online surveys or some respondents still prefer through hard copy. This study limits the antecedents of customer loyalty only from customer satisfaction, fairness of prices, and quality of service. This study suggests further studies are to add antecedents to other customer loyalty, and reduce the number of indicators relevant to respondents' willingness.

\section{Acknowledgement}

This research was funded by the Directorate of Research and Community Service, Directorate General of Research and Development Strengthening, Ministry of Research, Technology and Higher Education, in accordance with Research Contracts, Number: 017 / K1.1 / LT.1 / 2018

\section{Bibliography}

The first author named Imelda Sitinjak, SE., MSM, lecturer at the Faculty of Economics, HKBP Nommensen University since 2010, after previously working at PT. Jatayu Airlines, Radio KISS FM Medan, ULaMM PT. PNM (Persero), as well as members of the 
Indonesian Navigator organization. The first author was a graduate of the University of North Sumatra (S1), and a graduate of the University of Indonesia PPIM FEB (S2). The first author is a lecturer in strategic management, entrepreneurship, business ethics, introductory management and business introductory courses. The second author named Martin Luter Purba, SE., M.Sc, lecturer at the Faculty of Economics, University of HKBP Nommensen which is graduated from HKBP University Nommensen (S1), and graduated from the Postgraduate University of North Sumatra (S2).

\section{References}

Ananta Y [internet]. 2018. Investor Berjamaah Suntik Startup dari Tokped hingga Gojek. [Cited in 2018 December 30]. Available form https://www.cnbcindonesia.com/fintech/20181230163750-37-48470/investorberjamaah-suntik-startup-dari-tokped-hingga-gojek.

Bei L-T, Y-C Chiao. 2001. An Integrated Model for The Effects of Perceived Product, Perceived Price Fairness on Customer Satisfaction and Loyalty. Journal of Consumer Satisfaction, Dissatisfaction, and Complaining Behavior. 14: 125-140.

Berlianto MP. 2017. Pengaruh Kualitas Layanan-E, Kepuasan-E, Dan Kepercayaan-E Terhadap Kesetiaan-E Pada GO-JEK. Business Management Journal. 13(1).

Cristobal E, Flavian C, Guinaliu M. 2007. Perceived e-Service Quality (PeSQ) measurment validation and effects on customer satisfaction and web site loyalty. Managing Service Quality. 17(3): 317-340

European Committee for Standarization. 2002. Dalam Ngoc et al. 2017. Towards the Development of Quality Standards for Public Transport Service in Developing Countries: Analysis of Public Transport Users' Behavior. Transportation Research Procedia. 25: 4560-4579

Kotler P, Keller KL. 2009. Marketing Management 13th Ed. New Jersey: Pearson Education, Inc.

Mar'ati NC, Sudarwanto T. 2016. Pengaruh Kualitas Layanan Dan Harga Terhadap Kepuasan Pelanggan Jasa Transportasi Ojek Online (Studi Pada Konsumen GO-JEK Di Surabaya). [Skripsi]. Surabaya: Universitas Negeri Surabaya

Nistanto [internet]. 2016. Kebocoran GO-JEK Memuncak Rute Sehari-hari Pengguna Bisa Dilacak. [Cited in 2017 April 23]. Available from http://www.tekno.kompas.com/read/2016/01/20/16031307/Kebocoran.GO-

JEK.Memuncak.Rute.Sehari-hari.Pengguna.Bisa.Dilacak.

Polyorat K, Sophonsiri S. 2010. Pengaruh Hubungan Kualitas Layanan, Kepuasan dan Loyalitas. Journal of Global Business and Technology. 6(64): 2.

Purba RE. 2017. Pengaruh Kualitas Pelayanan dan Harga Terhadap Loyalitas Konsumen Dengan Kepuasan Konsumen Sebagai Variabel Intervening pada Pengguna Jasa GOJEK Di Mahasiswa Program Studi Manajemen Fakultas Ekonomi dan Bisnis Universitas Medan Area. [Tesis]. Medan: Universitas Medan Area

Quach S, Hewege C, V.Le. 2018. Expression and Transformation of Loyalty in a Contractual Service Setting: A Processual View. Australian Marketing Journal. 000: 1-12

Rizan M, Yulianti D, Rahmi. 2015. The Influence of Price And Service Quality Of Brand Image And Its Impact On Customer Satisfaction GO-JEK (Students Study On A State University Of Jakarta). Jurnal Riset Manajemen Sains Indonesia (JRMSI). 6(2).

Santoso AS, Nelloh LAM. 2017. User Satisfaction and Intention to Use Peer-to-Peer Online Transportation: A Replication Study. Procedia Computer Science. 124: 379-387.

Setyaji DI, Ngatno. 2016. Pengaruh Kualitas Pelayanan dan Kepuasan Konsumen terhadap Loyalitas Pelanggan (Studi Kasus pada Pelanggan GO-JEK di Semarang). [Skripsi]. Semarang: Jurusan Ilmu Administrasi Bisnis Fakultas Ilmu Sosial dan Ilmu Politik Universitas Diponegoro. 
Silalahi SL, Handayani PW, Munajat Q. 2017. SERVICE Quality Analysis for Online Transportation Services: Case Study of GO-JEK. Procedia Computer Science. 124: 487-495

Sinintya W [internet]. 2019. Jangan Kaget! Transaksi Gojek Capai Rp 177,5 T pada 2018. [Cited in 2019 January]. Available from https://www.cnbcindonesia.com/fintech/20190124162928-37-52241/jangan-kagettransaksi-gojek-capai-rp-1775-t-pada-2018.

Sitinjak I. 2018. Pengaruh Kewajaran Harga dan Kualitas Pelayanan Terhadap Loyalitas Pelanggan yang dimediasi oleh Kepuasan Pelanggan Jasa Ojek Online (Go-Ride) PT. GO-JEK Indonesia (Studi Empiris pada Mahasiswa UHN Medan). Simantek. 2(1): 5569.

Tjiptono F. 2008. Strategi Pemasaran edisi ketiga. Yogyakarta: Penerbit ANDI.

Turino H. 2016. Meretas Konsep Ekonomi Berbagi cetakan kedua. Jakarta: Kesumaputra Kreatif.

Wijanto SH. 2008. Structural Equation Modeling dengan LISREL 8.8: Konsep dan Tutorial. Yogyakarta: Graha Ilmu. 